\title{
Fatty acids in eggs of anchoveta Engraulis ringens during two contrasting winter spawning seasons
}

\author{
Leonardo R. Castro ${ }^{1,2, *}$, Gabriel Claramunt ${ }^{3}$, Humberto E. González ${ }^{4}$, María C. Krautz ${ }^{1,5}$, \\ Alejandra Llanos-Rivera ${ }^{1,6}$, Joyce Méndez ${ }^{1}$, Wolfgang Schneider ${ }^{2}$, Samuel Soto ${ }^{1}$ \\ ${ }^{1}$ Laboratorio de Oceanografía Pesquera y Ecología Larval, Departamento de Oceanografía, Universidad de Concepción, \\ Concepción, Chile \\ ${ }^{2}$ Departamento de Oceanografía, Centro FONDAP-COPAS, Universidad de Concepción, PO Box 160-C, Concepción, Chile \\ ${ }^{3}$ Departamento de Ciencias del Mar, Universidad Arturo Prat, Casilla 121, Iquique, Chile \\ ${ }^{4}$ Instituto de Bilogía Marina, Universidad Austral de Chile, Valdivia, Chile \\ ${ }^{5}$ Doctorado en Oceanografía, Universidad de Concepción, PO Box 160-C, Concepción, Chile \\ ${ }^{6}$ Unidad de Biotecnología Marina, Facultad de Ciencias Naturales y Oceanográficas, Universidad de Concepción, \\ PO Box 160-C, Concepción, Chile
}

\begin{abstract}
We assessed the fatty acid (FA) composition of anchoveta eggs collected from the plankton along with female anchoveta reproductive traits and environmental conditions during peak winter spawning in 2005 and 2007. Environmental conditions differed markedly between years at 3 continental shelf stations off Talcahuano, Chile, with a warmer, fresher water column in 2005 and a colder, saltier one in 2007 . We confirmed differences in sea surface temperature, measured both at the coastal egg collection stations and using satellite images over a broader area, caused by south winds that induced coastal upwelling in 2007. Winter 2005 was largely dominated by typical small omnivorous and carnivorous copepods (Oncaea and Oithona), whereas in 2007, larger herbivorous calanoid copepods (with high polyunsaturated FA [PUFA] levels that are typical of upwelling conditions) and diatom abundance (indicated by the docosahexaenoic/eicosapentaenoic acids [DHA/EPA] ratio) increased. Although anchoveta eggs were smaller in 2005, batch size and relative fecundity per female were greater in 2007 because of larger ovaries. While relative amounts of saturated (SAFA), monounsaturated (MUFA) FA, and PUFA in anchoveta eggs in 2005 were within the ranges reported for marine fish species, in 2007, PUFA were in the upper and SAFA and MUFA in the lower ranges. Our results suggest that the higher PUFA and lower DHA/EPA values for anchoveta eggs in 2007 may have resulted from increased consumption of larger herbivorous copepods or direct consumption of larger phytoplankton, prey typical of cold upwelling conditions. Conversely, elevated SAFA and MUFA levels in 2005 may have resulted from consumption of smaller omnivorous/carnivorous copepods by adult fish.
\end{abstract}

KEY WORDS: Fatty acids $\cdot$ Anchovies $\cdot$ Fish eggs $\cdot$ Upwelling $\cdot$ Egg volume $\cdot$ Humboldt Current

\section{INTRODUCTION}

Fish populations with protracted reproductive seasons usually face contrasting environmental conditions during this period. From winter through spring, the fish commonly experience variations in environmental conditions such as the thermal structure of the water column and also in biological production, which may be particularly evident at mid-latitudes. Different habitat characteristics may affect the female fish metabolism and the amount of energy devoted to gametogenesis and, ultimately, the reproductive output. Female reproductive conditions change during the spawning season - even when environmental conditions do not - due to shifting energy allocations during the reproductive season. Thus, under natural condi- 
tions, most multiple spawner fish populations are expected to produce eggs with distinct levels of quality at different times in the season.

A number of morphological and biochemical characteristics have been suggested as indicators of egg quality. Those associated with size (volume, weight) are some of the most commonly cited in the literature. Egg size has been reported to vary with latitude and also during the spawning season (Blaxter \& Hempel 1963, Ciechomski 1973, Llanos-Rivera \& Castro 2004). Larger egg sizes are often thought to be advantageous under environmental conditions in which larger hatching larvae would have a better chance for survival given their greater nutritional reserves, increased capability to search for food, or enhanced ability to avoid predators (Chambers 1997, Rideout et al. 2005). Other indicators of egg quality are egg shape, transparency, buoyancy, number and location of oil droplets, elemental composition, cell symmetry, and biochemical content (Evans et al. 1996, Pickova et al. 1997, Shields et al. 1997, Carrillo et al. 2000, Lahnsteiner \& Patarnello 2005, Bransden et al. 2007). Lipids and proteins are 2 biochemical compounds that affect fish egg quality, and reports indicate that the lipid and protein contents of eggs vary from the onset of the spawning season to its end. Off the Iberian Peninsula, concentrations of lipids, carbohydrates, and proteins decrease in Sardina pilchardus eggs as the spawning season progresses from winter to mid-spring, suggesting that better-quality eggs are spawned at low winter temperatures and when larval food is less abundant, thereby enhancing larval growth and survival (Riveiro et al. 2000, 2004).

Fatty acids (FA) are reported to have a strong impact on egg quality, ultimately modifying offspring viability. Eicosapentaenoic acid (EPA, 20:5 n-3) and docosahexaenoic acid (DHA, 22:6 n-3) are 2 FA that affect egg quality, influencing hatch success or young larval development (Sargent et al. 1999). In studies of cod, differences in hatching success, early embryonic cleavage patterns, and egg FA compositions for individuals from different stocks have also been reported (Pickova et al. 1997). Rainuzzo et al. (1997) reviewed the significance of lipids for early stages of marine fishes; in some studies reported therein, variations of DHA and EPA in experimental diets fed to spawning females were found to affect hatch success, larval development, and egg pigmentation.

As in many invertebrates (Mayzaud et al. 1999), FA from the food web are readily incorporated into young and adult fish. Examples of these range from demersal fishes (St. John \& Lund 1996, Dwyer et al. 2003) to mesopelagic myctophid fishes (Saito \& Murata 1998) to forage fishes at high latitudes (Iverson et al. 2002). A correspondence between the feeding environment and fish composition has also been observed in very productive zones such as upwelling areas (Lasker \& Theilacker 1962) and could be a characteristic of planktivorous fish in short food web systems (Njinkoué et al. 2002). The body tissues of female fish rapidly incorporate seasonal variations in food quality in terms of available FA. In clupeids such as Sardinops melanostictus, the FA composition of the muscle and gonads resembles precisely that of the plankton, indicating a clear association between differences in the FA composition of these fish tissues and seasonal variations in the plankton (Shirai et al. 2002). Likewise, a study of Sardina pilchardus off the Iberian Peninsula by Garrido et al. (2007) revealed a relationship between the essential FA in the muscle and those in the gonads, suggesting that lipids pass from one to the other during different months of the spawning season. In some fish populations, it may be common for the essential FA (DHA, EPA) of the food web to be incorporated into the intermediate tissues and then into the gonads.

The anchoveta Engraulis ringens is an indeterminate multiple spawner. This small pelagic fish inhabits the Humboldt Current from 4 to $42^{\circ} \mathrm{S}$. The environmental conditions vary widely in this latitudinal range. The southernmost anchoveta population is located off central Chile, with maximum fish abundances around 38 to $39^{\circ} \mathrm{S}$. This anchoveta stock spawns in winter, when the temperature is lower than in northern Chile or Peru (home to the largest stock), wind-induced turbulence is stronger, and productivity is reduced by the lack of coastal upwelling and a seasonal light limitation (Castro et al. 2000, Castro 2001). Reports show that the volume of oocytes and subsequent early life history traits such as egg size, larval size, and yolk volume at hatching increase with latitude, suggesting that traits associated with egg and larval volume are determined during oocyte development in the gonads and also that environmental conditions may be able to modify these traits during early ontogeny (Castro et al. 2002, LlanosRivera \& Castro 2004, 2006, Leal et al. 2009).

The biochemical contents of anchoveta eggs have also been reported to vary according to the distinct environmental conditions at different latitudes and also throughout the spawning season (Castro et al. 2009, Krautz et al. 2010). Total lipid, protein, cholesterol, and triacylglycerol (TAG) concentrations are higher at the beginning of the spawning season in winter, when environmental conditions in the southern spawning habitat are the harshest of the entire spawning season. These lipid variations have been interpreted as beneficial for the younger life stages during the onset of winter spawning, when larval feeding and survival may be complicated by environmental conditions such as lower prey availability and higher windinduced turbulence. 
However, the lipid composition of the eggs (other than TAG and cholesterol) should also be expected to vary during the spawning season according to the type of food consumed by the adult females, as observed in other clupeiform fishes (Shirai et al. 2002, Garrido et al. 2007). Because environmental conditions also vary on time scales other than seasonal (i.e. interannual, interdecadal), we can also expect alterations in the food web and prey field and, consequently, in the composition of eggs spawned under different habitat conditions between years in some areas.

In this study, we assessed the FA composition of anchoveta eggs from the southernmost population during the peak spawning months in 2 winter seasons. This is the first FA analysis done on the eggs of this key pelagic species of the Humboldt Current. Our analyses included (1) FA determinations for eggs in the winters of 2005 and 2007 under contrasting habitat conditions in terms of temperature and food availability for females, (2) size determinations of eggs in the plankton, and (3) an assessment of the reproductive traits of adult females spawning in the same area and seasons. Basically, we set out to link common variations in habitat characteristics, reproductive traits, and egg quality indicators under natural conditions for one of the most abundant key pelagic species in the Humboldt Current (Cury et al. 2000, Krautz et al. 2007).

\section{MATERIALS AND METHODS}

Monthly cruises were made to 3 coastal (3 to 5 nautical miles offshore) oceanographic stations off Talcahuano, central Chile, on board the RV 'Kay-Kay' during the main anchoveta spawning season, from mid-winter (July) to early spring (September) in 2005 and 2007. The sea surface temperature (SST) was recorded on board (bucket temperature) at each station. In 2007, CTD casts were also done from the surface to $\sim 40 \mathrm{~m}$ depth. At each station, ichthyoplankton samples were gently collected with Bongo nets (300 $\mu \mathrm{m}$ mesh, $60 \mathrm{~cm}$ diameter, equipped with flowmeters) from the surface down to $20 \mathrm{~m}$. Plankton samples were maintained in 41 buckets filled with seawater and transported to the Marine Biology Station in Dichato within $2 \mathrm{~h}$ of collection; samples were transported in $60 \mathrm{l}$ coolers, in the dark, and at a constant temperature. At the laboratory, anchoveta eggs that had not yet reached the embryo stage $(<1 \mathrm{~d}$ old, corresponding to Stages 1-3, after Fisher 1958) were separated and 2 to 4 subsamples (200 eggs each) were deep-frozen in liquid nitrogen for FA analyses. Another 2 subsamples (50 eggs each) were separated for wet and dry wt determinations, and a last subsample ( 200 eggs) was separated for egg size measure- ments. The rest of the zooplankton sample was then preserved in $5 \%$ formaldehyde for mesozooplankton identification and quantification.

Wet and dry egg weights were determined with a analytical balance (0.0001 $\mathrm{g}$ resolution) after initially drying the subsample of eggs with absorbent paper and then drying the same subsample for $24 \mathrm{~h}$ at $60^{\circ} \mathrm{C}$. The FA determinations were carried out by gas chromatography (GC) with a flame ionization detector (FID) after an hexane extraction and an esterification using sodium methoxide following methods proposed by Cantellops et al. (1999).

Eggs preserved in formaldehyde were measured under a binocular microscope, along the (a) longest and (b) shortest axes; these measurements were used to estimate egg volume utilizing the equation for ellipsoids: (4/3) $\pi \mathrm{ab}^{2}$. We used Zooimage software (www. sciviews.org/zooimage/index.html) to identify and quantify zooplankton; first staining and scanning variable fractions of the formalin-preserved mesozooplankton samples and then analyzing them with the aforementioned program. The program also grouped the different species into major zooplankton groups and classified the organisms in 2 size ranges (300$1000 \mu \mathrm{m}$ and $>1000 \mu \mathrm{m}$ ) based on body length.

Data on reproductive traits were obtained from adult females collected during annual winter surveys and used for reproductive stock biomass assessments (daily egg production method; Parker 1980) of anchoveta in central Chile; these assessments were carried out by the same research group in August and September 2005 and 2007 in the same study area used to collect eggs for FA determinations. Reproductive data included number of oocytes per unit of ovary weight, ovary and body weight, and batch fecundity. Batch fecundity (number of oocytes liberated by a female in 1 spawning event) was estimated based on hydrated females using the gravimetric method described by Hunter \& Goldberg (1980), excluding females with new postovulatory follicles. The oocyte counts were carried out on 3 ovary sections of $\sim 0.2 \mathrm{~g}$ each, from which at least 100 hydrated oocytes were observed. We analyzed 23 females in 2005 and 92 females in 2007.

Additional oceanographic data (temperature and salinity profiles) were obtained from the COPAS Time Series at Stn 18 off Talcahuano (www.copas.udec.cl/ eng/research/serie/). Plankton samples (diatoms, dinoflagellates and ciliates) were obtained with Niskin bottles at $10 \mathrm{~m}$ depth and preserved with borax-buffered formaldehyde. These samples were counted and identified under an inverted microscope (Carl Zeiss Axiovert 200) following the methodology of Utermöhl (1958). This station is located on the continental shelf in our study area and has been monitored every month since 2002 by the Center of Oceanographic Research 
in the Eastern South Pacific (FONDAP-COPAS Center) of the Universidad de Concepción. Also, SST satellite images (NOAA 14) were obtained daily during the middle of the 2005 and 2007 sampling seasons. Because of cloud cover, composite images of up to $3 \mathrm{~d}$ were processed and are presented in this study. Data are presented as mean $\pm \mathrm{SD}$.

\section{RESULTS}

\section{Fatty acids}

In 2005 and 2007, polyunsaturated fatty acids (PUFA) made up the largest proportion of the FA, followed by saturated (SAFA) and monounsaturated (MUFA) fatty acids (Table 1). The proportions of these 3 FA classes did not vary much during the 3 months sampled each year. SAFA and MUFA constituted a larger percentage of the total FA in 2005 than in 2007, with significant differences between years in August and September $(\mathrm{p}<$ $0.05)$, whereas the proportion of PUFA was greater in 2007 than in 2005, with significant differences between July and September $(\mathrm{p}<0.05)$.
The FA 22:6 n-3 (DHA) $(22.1 \pm 1.8)$ constituted the largest mean percentage of the eggs in 2005, followed by 16:0 (palmitic acid) (19.7 \pm 0.8$)$ and 20:5 n-3 (EPA) $(15.7 \pm 1.7)$. In 2007, however, EPA (43.5 \pm 10.7) made up the largest proportion of the FA, followed by DHA $(15.6 \pm 4.7)$ and 18:1 n-9 (6.7 \pm 1.8$)$. The 20:4 n-6 (arachidonic acids, AA) proportions were $1.2( \pm 0.2)$ and $2.8( \pm 0.8)$ in 2005 and 2007, respectively. The 3 most abundant FA for each year constituted between 57 and $66 \%$ of the total.

Of the four n-3 PUFA studied, two showed a larger proportion in 2007 than in 2005 (Fig. 1); these were $18: 4 \mathrm{n}-3\left(t_{\text {calc }}=5.14 ; \mathrm{p}=0.0002\right)$, and EPA $\left(t_{\text {calc }}=4.5 ; \mathrm{p}=\right.$ $0.0006)$. The other 2 FA (18:3 n-3 and DHA) did not differ between years. Interestingly, the proportion of 18:3 n-3 (linolenic acid) increased with the spawning season progressing from July to August in both years. Araquidonic acid proportion also increased during $2007\left(t_{\text {calc }}=3.4 ; \mathrm{p}=0.0047\right)$.

The DHA/EPA ratios of the mean monthly percentages were higher in $2005(1.4 \pm 1.3)$ than in 2007 $(0.4 \pm 0.4)\left(t_{\text {calc }}=2.9 ; \mathrm{p}=0.013\right)$. In 2005 , these mean monthly ratios were very similar throughout the season (Table 1).

Table 1. Engraulis ringens. Fatty acids (FAs) in anchoveta eggs during winters 2005 and 2007 off central Chile, expressed as percentage (means $\pm \mathrm{SD}$ ) of total FA. FAs: saturated (SAFA), monounsaturated (MUFA), polyunsaturated (PUFA), docosahexaenoic (DHA) and eicosapentaenoic (EPA) acid

\begin{tabular}{|c|c|c|c|c|c|c|c|c|}
\hline \multirow[t]{2}{*}{ FA } & \multicolumn{3}{|c|}{2005} & \multicolumn{3}{|c|}{2007} & \multirow{2}{*}{$\begin{array}{c}2005 \\
\text { Jul-Sep }\end{array}$} & \multirow{2}{*}{$\begin{array}{c}2007 \\
\text { Jul-Sep }\end{array}$} \\
\hline & July & August & September & July & August & September & & \\
\hline $12: 0$ & $0.6 \pm 0.4$ & $0.6 \pm 0.2$ & $0.6 \pm 0.8$ & $0.4 \pm 0.1$ & $0.6 \pm 0.0$ & $0.4 \pm 0.2$ & $0.6 \pm 0.0$ & $0.5 \pm 0.1$ \\
\hline $14: 0$ & $3.4 \pm 0.3$ & $3.5 \pm 0.5$ & $3.0 \pm 0.8$ & $0.6 \pm 0.2$ & $0.4 \pm 0.1$ & $0.4 \pm 0.2$ & $3.3 \pm 0.3$ & $0.5 \pm 0.1$ \\
\hline $15: 0$ & $0.6 \pm 0.3$ & $0.4 \pm 0.3$ & $0.5 \pm 0.2$ & $0.9 \pm 0.5$ & $0.3 \pm 0.1$ & $0.2 \pm 0.0$ & $0.5 \pm 0.1$ & $0.5 \pm 0.4$ \\
\hline $16: 0$ & $20.5 \pm 2.8$ & $18.8 \pm 0.8$ & $22.8 \pm 2.0$ & $5.6 \pm 0.0$ & $5.0 \pm 0.2$ & $5.8 \pm 1.8$ & $20.7 \pm 2.0$ & $5.5 \pm 0.4$ \\
\hline $16: 1 \mathrm{n}-7$ & $4.3 \pm 0.4$ & $4.6 \pm 0.1$ & $4.4 \pm 0.5$ & $1.7 \pm 1.0$ & $2.8 \pm 0.0$ & $3.1 \pm 0.7$ & $4.5 \pm 0.1$ & $2.5 \pm 0.7$ \\
\hline $17: 0$ & $2.7 \pm 1.4$ & $1.9 \pm 0.9$ & $1.2 \pm 0.2$ & $0.3 \pm 0.0$ & $0.6 \pm 0.1$ & $0.6 \pm 0.0$ & $1.9 \pm 0.7$ & $0.5 \pm 0.1$ \\
\hline $17: 1$ & $1.1 \pm 0.3$ & $0.9 \pm 0.2$ & $0.8 \pm 0.2$ & $1.1 \pm 1.2$ & $0.6 \pm 0.1$ & $0.7 \pm 0.2$ & $0.9 \pm 0.2$ & $0.8 \pm 0.3$ \\
\hline $18: 0$ & $3.4 \pm 0.8$ & $3.1 \pm 0.3$ & $3.8 \pm 0.4$ & $4.7 \pm 1.4$ & $1.9 \pm 0.3$ & $4.5 \pm 1.5$ & $3.4 \pm 0.4$ & $3.7 \pm 1.5$ \\
\hline $18: 1 \mathrm{n}-9$ & $13.3 \pm 2.3$ & $10.8 \pm 0.9$ & $13.2 \pm 0.5$ & $6.3 \pm 1.5$ & $5.0 \pm 0.8$ & $8.7 \pm 5.5$ & $12.4 \pm 1.4$ & $6.7 \pm 1.8$ \\
\hline $18: 2 \mathrm{n}-6$ & $2.7 \pm 1.0$ & $2.0 \pm 0.7$ & $2.0 \pm 0.4$ & $2.0 \pm 1.0$ & $2.2 \pm 0.4$ & $2.8 \pm 2.2$ & $2.2 \pm 0.4$ & $2.3 \pm 0.4$ \\
\hline $18: 4 \mathrm{n}-3$ & $0.9 \pm 0.5$ & $0.7 \pm 0.2$ & $0.8 \pm 0.6$ & $3.0 \pm 0.7$ & $1.5 \pm 0.3$ & $3.1 \pm 0.0$ & $0.8 \pm 0.1$ & $2.5 \pm 0.9$ \\
\hline $18: 3 n-3$ & $0.6 \pm 0.3$ & $1.0 \pm 0.5$ & $1.6 \pm 0.5$ & $0.6 \pm 0.5$ & $1.1 \pm 0.3$ & $1.3 \pm 0.8$ & $1.1 \pm 0.5$ & $1.0 \pm 0.4$ \\
\hline $20: 0$ & $0.4 \pm 0.4$ & $0.7 \pm 0.1$ & $0.1 \pm 0.1$ & $1.0 \pm 0.0$ & $0.5 \pm 0.1$ & $0.3 \pm 0.2$ & $0.4 \pm 0.3$ & $0.3 \pm 0.2$ \\
\hline $20: 1$ n-9 & $0.5 \pm 0.4$ & $0.7 \pm 0.7$ & $0.4 \pm 0.5$ & $0.8 \pm 0.4$ & $0.7 \pm 0.2$ & $0.7 \pm 0.3$ & $0.6 \pm 0.2$ & $0.7 \pm 0.1$ \\
\hline $20: 4 n-6$ & $1.3 \pm 0.2$ & $1.0 \pm 0.2$ & $0.6 \pm 0.8$ & $3.6 \pm 2.5$ & $2.0 \pm 0.6$ & $2.7 \pm 0.6$ & $1.0 \pm 0.4$ & $2.8 \pm 0.8$ \\
\hline $22: 0$ & $0.3 \pm 0.0$ & $0.4 \pm 0.0$ & $0.4 \pm 0.1$ & $0.7 \pm 0.2$ & $0.5 \pm 0.2$ & $0.7 \pm 0.0$ & $0.4 \pm 0.1$ & $0.6 \pm 0.1$ \\
\hline $22: 1 \mathrm{n}-11$ & $0.2 \pm 0.2$ & $0.1 \pm 0.1$ & $1.3 \pm 1.7$ & $0.3 \pm 0.1$ & $0.4 \pm 0.2$ & $0.2 \pm 0.2$ & $0.5 \pm 0.7$ & $0.3 \pm 0.1$ \\
\hline $20: 5 n-3$ & $14.0 \pm 2.3$ & $17.3 \pm 0.5$ & $13.5 \pm 2.7$ & $34.7 \pm 29.8$ & $55.4 \pm 2.5$ & $40.4 \pm 23.1$ & $15.0 \pm 2.1$ & $43.5 \pm 10.7$ \\
\hline $22: 3$ & $0.4 \pm 0.2$ & $0.5 \pm 0.2$ & $0.5 \pm 0.0$ & $1.1 \pm 0.3$ & $0.6 \pm 0.1$ & $0.7 \pm 0.2$ & $0.5 \pm 0.0$ & $0.8 \pm 0.2$ \\
\hline $22: 6 n-3$ & $20.3 \pm 3.6$ & $23.9 \pm 0.3$ & $18.7 \pm 2.5$ & $21.1 \pm 14.0$ & $12.5 \pm 0.2$ & $13.3 \pm 4.2$ & $21.0 \pm 2.6$ & $15.6 \pm 4.7$ \\
\hline DHA/EPA & $1.5 \pm 0.2$ & $1.4 \pm 0.1$ & $1.4 \pm 0.1$ & $1.2 \pm 1.5$ & $0.2 \pm 0.0$ & $0.4 \pm 0.3$ & $1.4 \pm 0.0$ & $0.6 \pm 0.5$ \\
\hline$\Sigma$ SAFA & $31.7 \pm 2.0$ & $29.5 \pm 0.1$ & $32.4 \pm 0.2$ & $13.2 \pm 2.2$ & $9.8 \pm 0.6$ & $12.9 \pm 3.4$ & $31.2 \pm 1.5$ & $11.9 \pm 1.9$ \\
\hline$\Sigma$ MUFA & $19.4 \pm 2.0$ & $17.1 \pm 0.1$ & $20.1 \pm 3.5$ & $10.2 \pm 2.2$ & $9.5 \pm 0.9$ & $13.4 \pm 6.0$ & $18.9 \pm 1.5$ & $11.0 \pm 2.0$ \\
\hline$\Sigma$ PUFA & $40.3 \pm 4.5$ & $46.4 \pm 1.2$ & $37.6 \pm 4.7$ & $66.0 \pm 12.4$ & $75.3 \pm 1.9$ & $64.3 \pm 15.1$ & $41.5 \pm 4.5$ & $68.6 \pm 5.9$ \\
\hline$\Sigma \mathrm{FA}$ & $91.5 \pm 2.0$ & $93.1 \pm 1.1$ & $90.1 \pm 1.5$ & $89.4 \pm 7.9$ & $94.6 \pm 0.4$ & $90.6 \pm 5.7$ & $91.6 \pm 1.5$ & $91.5 \pm 2.7$ \\
\hline
\end{tabular}




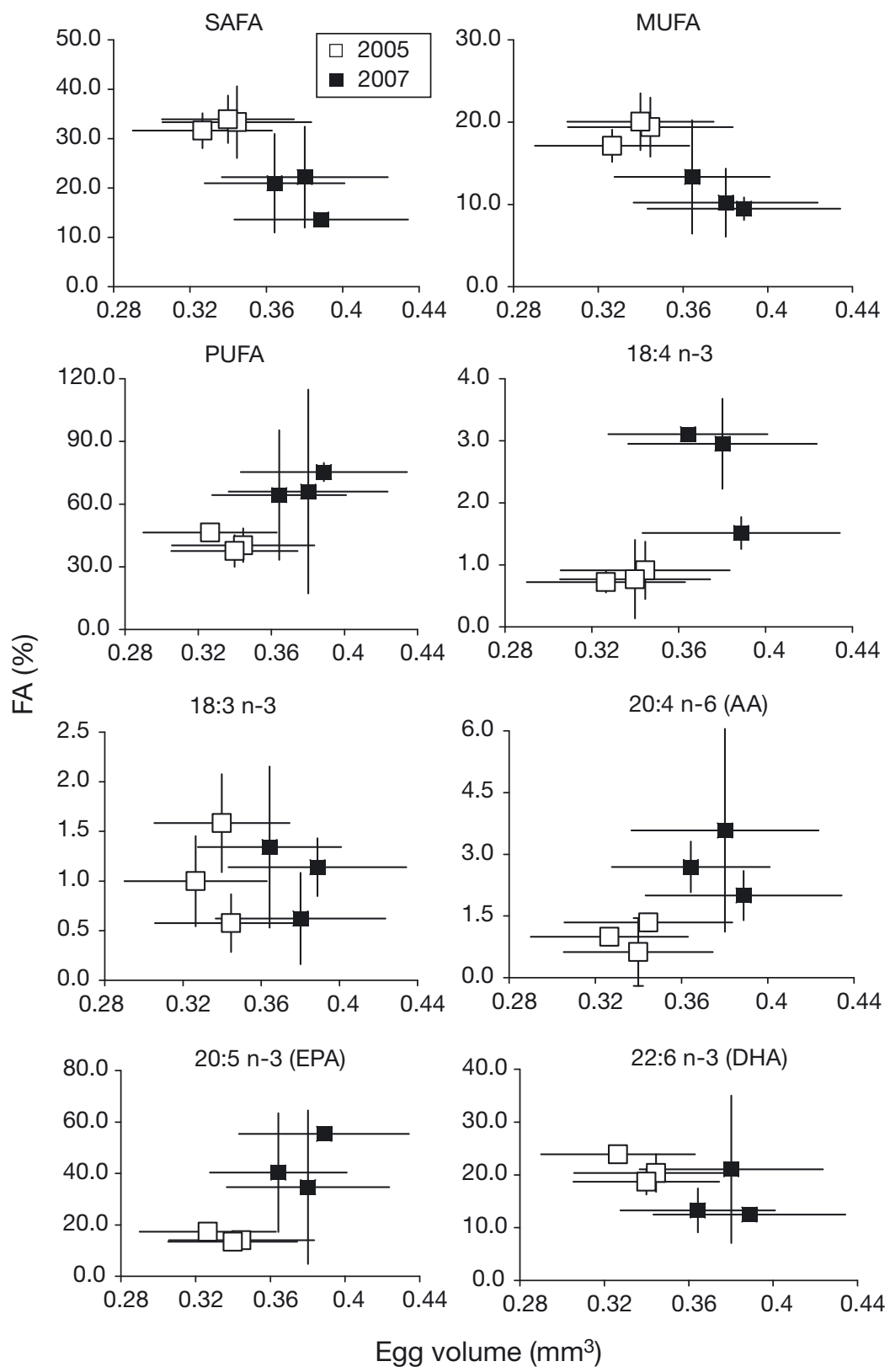

Fig. 1. Engraulis ringens. Volume $\left(\mathrm{mm}^{3}\right)$ and fatty acids (FAs) contents of anchoveta eggs collected during 2005 and 2007 cruises to the coastal station off Talcahuano, central Chile. Data: monthly mean \pm SD. FAs: saturated (SAFA), monounsaturated (MUFA), polyunsaturated (PUFA), arachidonic acid (AA), eicosapentaenoic acid (EPA), docosahexaenoic acid (DHA)

Table 2. Engraulis ringens. Reproductive traits of adult female anchoveta during the winter spawning season off central Chile, 2005 and 2007. Data: means \pm SD

\begin{tabular}{|c|c|c|c|c|c|}
\hline & $\begin{array}{c}\text { Batch } \\
\text { fecundity } \\
\text { (no. oocytes) }\end{array}$ & $\begin{array}{l}\text { Gonad } \\
\text { weight } \\
\text { (g) }\end{array}$ & $\begin{array}{c}\text { Oocytes/ } \\
\text { gonad weight } \\
\text { (no. oocytes } \\
\mathrm{g}^{-1} \text { ) }\end{array}$ & $\begin{array}{c}\text { Relative } \\
\text { fecundity } \\
\text { (no. oocytes } \\
\mathrm{g}^{-1} \text { female) }\end{array}$ & $\begin{array}{c}\text { Egg } \\
\text { volume } \\
\left(\mathrm{mm}^{3}\right)\end{array}$ \\
\hline 2005 & $4921 \pm 2288.2$ & $1.56 \pm 0.78$ & $3210.0 \pm 510.3$ & $306 \pm 78.1$ & $0.336 \pm 0.009$ \\
\hline 2007 & $8903 \pm 3102.6$ & $3.03 \pm 1.12$ & $2988.7 \pm 478.1$ & $416 \pm 90.6$ & $0.377 \pm 0.012$ \\
\hline
\end{tabular}

\section{Reproductive traits}

The mean number of oocytes per gram of ovary was $~ 10 \%$ lower in 2007 $(2988 \pm 478)$ than in $2005(3210 \pm 510)$. However, the mean female gonad weights were much higher ( 50\%) in $2007\left(t_{\text {calc }}=5.96 ; \mathrm{p}=0.0001\right)$, leading to a similar proportion of increased mean batch fecundity in 2007 (Table 2). The effect of the female's size was discarded by a regression between body weight and ovary weight forced to the origin because this indicated a significantly $(\mathrm{p}<0.05)$ higher slope in 2007 $\left(y=0.144 x_{i} \mathrm{p}<0.05\right)$ than in $2005(y=$ $\left.0.101 x_{i} \mathrm{p}<0.05\right)$. The results of the regression between batch fecundity and body weight were similar $(y=$ $313.9 x$ for 2005 and $y=419.9 x$ for 2007; $p<0.05$ in both years). Therefore, all reproductive parameters measured were higher in 2007 for the same female size.

The eggs from the plankton were larger in winter 2007 than in winter 2005 (Table 2). The series of plots showing monthly mean fractions (\%) of FA and mean monthly egg volumes indicates a higher proportion of SAFA and MUFA in lower-volume anchoveta eggs from the plankton and a positive trend in PUFA as egg volume increases. Of the PUFA, 18:4 n-3, AA, and EPA show the same increasing trend with egg volume, while DHA shows an inverse trend and decreases with increasing egg volume (Fig. 1).

\section{Environmental conditions}

The environmental conditions also differed between the winters of 2005 and 2007. In 2005, the mean SST at the 3 sampled oceanographic stations was higher by $\sim 1^{\circ} \mathrm{C}$ than in winter 2007 . On a larger spatial scale, SST images of the main spawning zone in central Chile obtained for August and September also showed that winter 2005 was 1 to $2{ }^{\circ} \mathrm{C}$ warmer (Fig. 2).

Within the larger time frame of our 7 yr time-series of oceanographic measurements at Stn 18, which started in 
2002, the mean temperature of the water column was lowest in the second half of $2007\left(1^{\circ} \mathrm{C}\right.$ colder $)$. Surface salinity, in turn, was about 1 psu higher in winter 2007 - in contrast to winter 2005, when the lowest salinities were observed in shallow waters-along with the highest temperatures throughout the water column (Fig. 3).
The series of plots showing monthly mean fractions of \% FA and of SST during the cruises indicated higher SAFA and MUFA but lower PUFA with higher temperatures. Reciprocal to their increasing trend with increasing egg volume, the 3 PUFA (18:4 n-3, AA, EPA) showed a decreasing trend with temperature. Conversely, DHA increased with SST (Fig. 4).
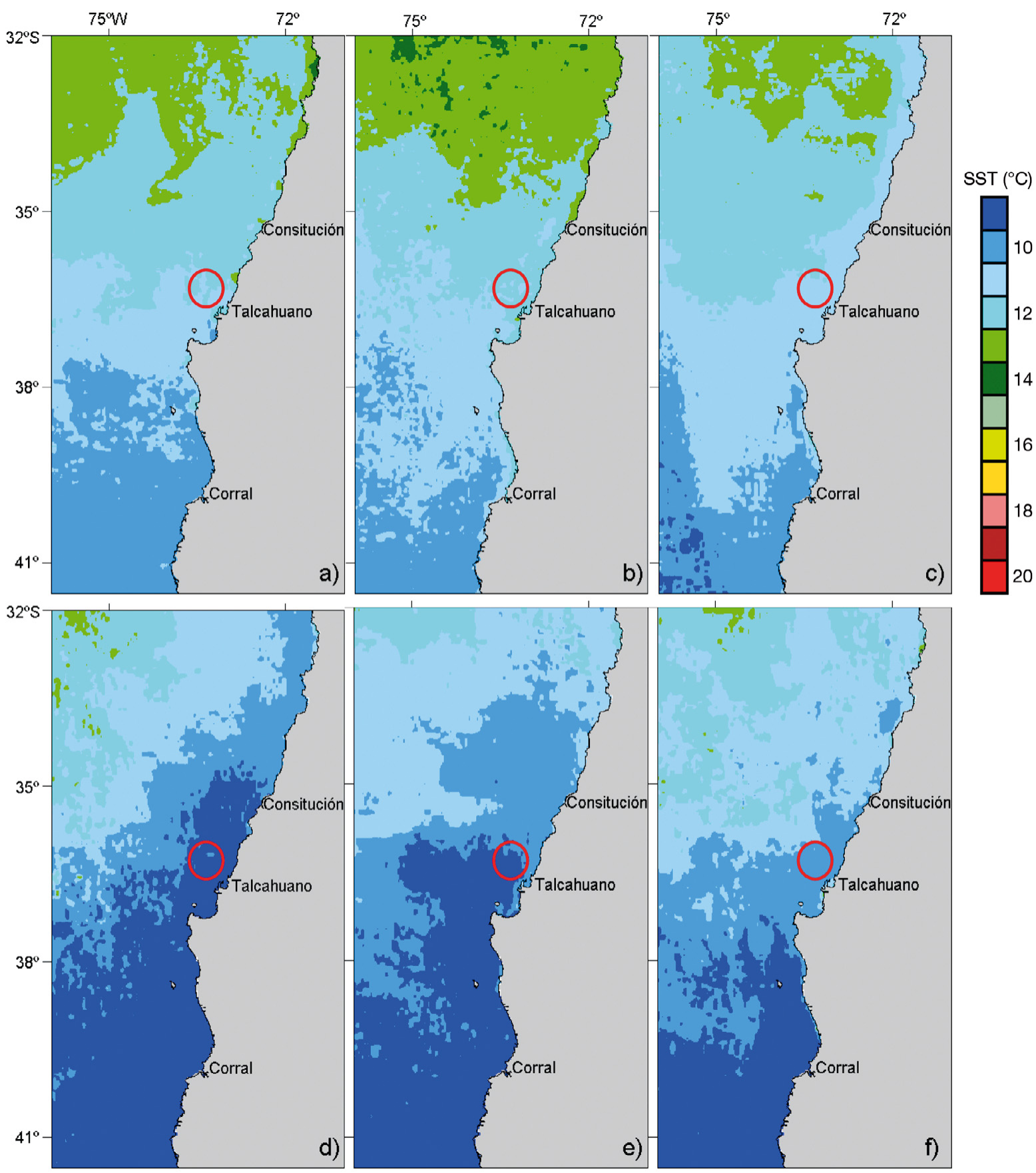

Fig. 2. Sea surface temperature (SST; $\left.{ }^{\circ} \mathrm{C}\right)$ composites from satellite images obtained in mid-winters 2005 and 2007 . Upper panels: (a) 20-24 Aug 2005, (b) 30 Aug-3 Sep 2005, (c) 9-13 Sep 2005. Lower panels: (d) 26-27 Aug 2007, (e) 3-4 Sep 2007, and (f) 10-11 Sep 2007. Red circle: area sampled 


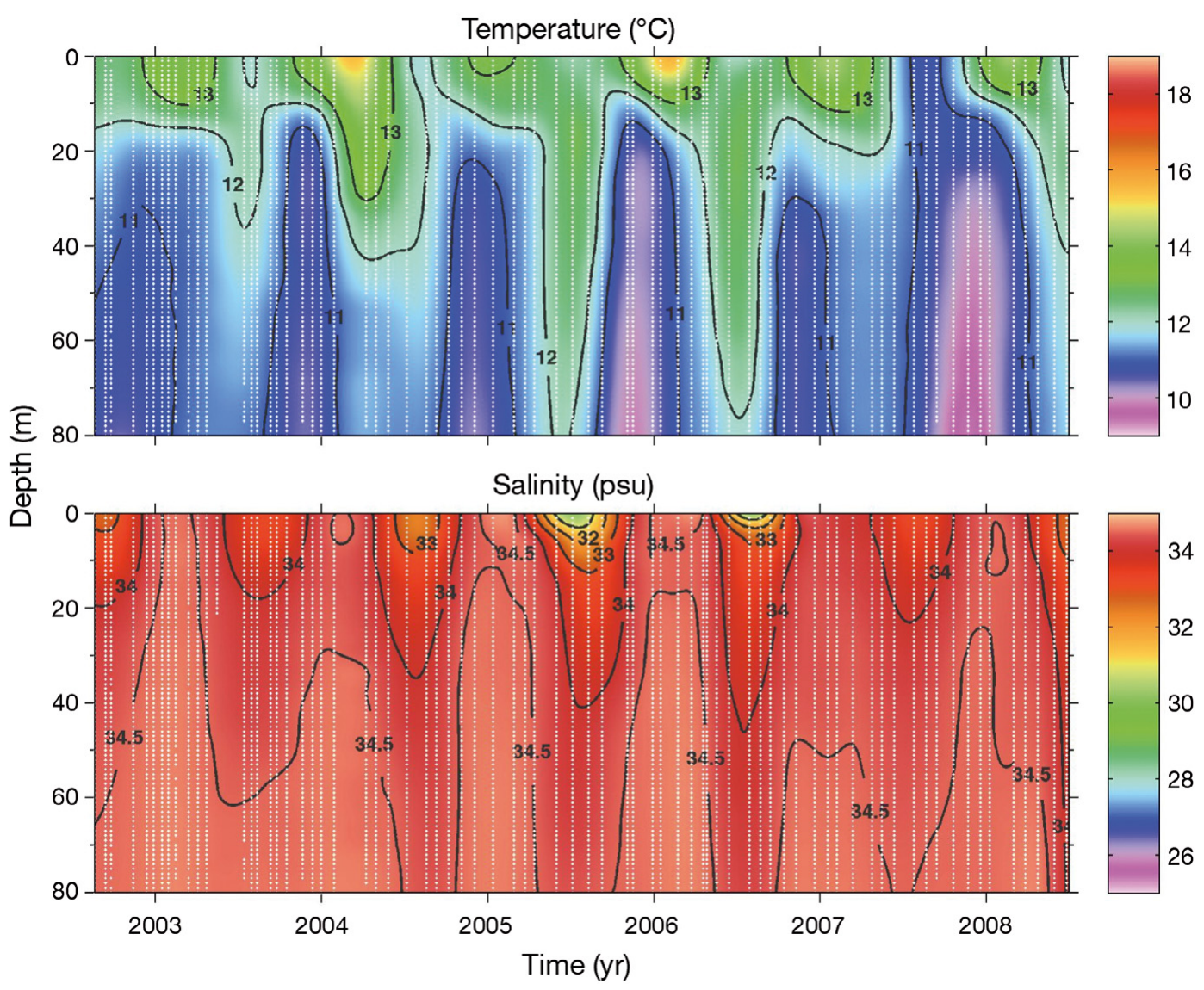

Fig. 3. Temporal section of temperature $\left({ }^{\circ} \mathrm{C}\right)$ and salinity (psu) from a time-series of monthly cruises (2002-2007) to Stn 18 off Talcahuano, central Chile

The microplankton items identified included diatoms, dinoflagellates, ciliates, and other less abundant items (nauplii, copepods eggs). Among diatoms, Skeletonema, Chaetoceros, Thalassiosira were the most abundant genera in both years and total diatom abundance increased from 2005 to 2007 (Figs. 5 \& 6). Dinoflagellates and ciliates were the most abundant taxa of the microzooplankton, and their abundance also increased in 2007. Whereas dinoflagellates and ciliates were more abundant at the beginning of winter (July to August) in 2005, their abundance and that of diatoms increased to the end of the season (September) in 2007. The analyses of the mesozooplankton samples collected during the research cruises showed that 2 major groups (copepods, appendicularians) dominated mesozooplankton. Copepods were dominant in both years (by more than one order of magnitude). Their total abundance shifted from a lower density in 2005 (198.5 ind. $\mathrm{m}^{-3}$ ) to a higher density in 2007 (315.7 ind. $\mathrm{m}^{-3}$ ). More changes were observed in the copepod composition: whereas Oncaeidae were clearly the most abundant in 2005, 2 yr later, the Calanidae had increased to abundances similar to those of the Oncaidae in 2005 (Fig. 6).

\section{DISCUSSION}

We assessed the FA composition of eggs present in the plankton during peak (winter) anchoveta spawning periods in 2 years, along with the reproductive traits of spawning females and environmental conditions. Our results showed variations in habitat characteristics (seawater temperature, food for adult fishes), reproductive traits (number of oocytes per gram of ovary, female fecundity, egg volume), and spawned egg quality as estimated by FA composition. Differences in habitat characteristics are not uncommon in these types of ecosystems and may be the result of normal inter-annual variability at mid-latitudes or the result of extreme conditions such as El Niño or La Niña events, which regularly occur along the Humboldt Current. Variations in the number of eggs per gram of ovary have not been reported for anchoveta at this latitude. However, inter-annual variations in reproductive traits such as fecundity or oocyte and egg sizes have already been reported for several populations located along the Humboldt Current (Ayon 2000, Castro et al. 2000, Llanos-Rivera \& Castro 2004, 2006, Castro et al. 2009). Finally, variations in egg quality in 

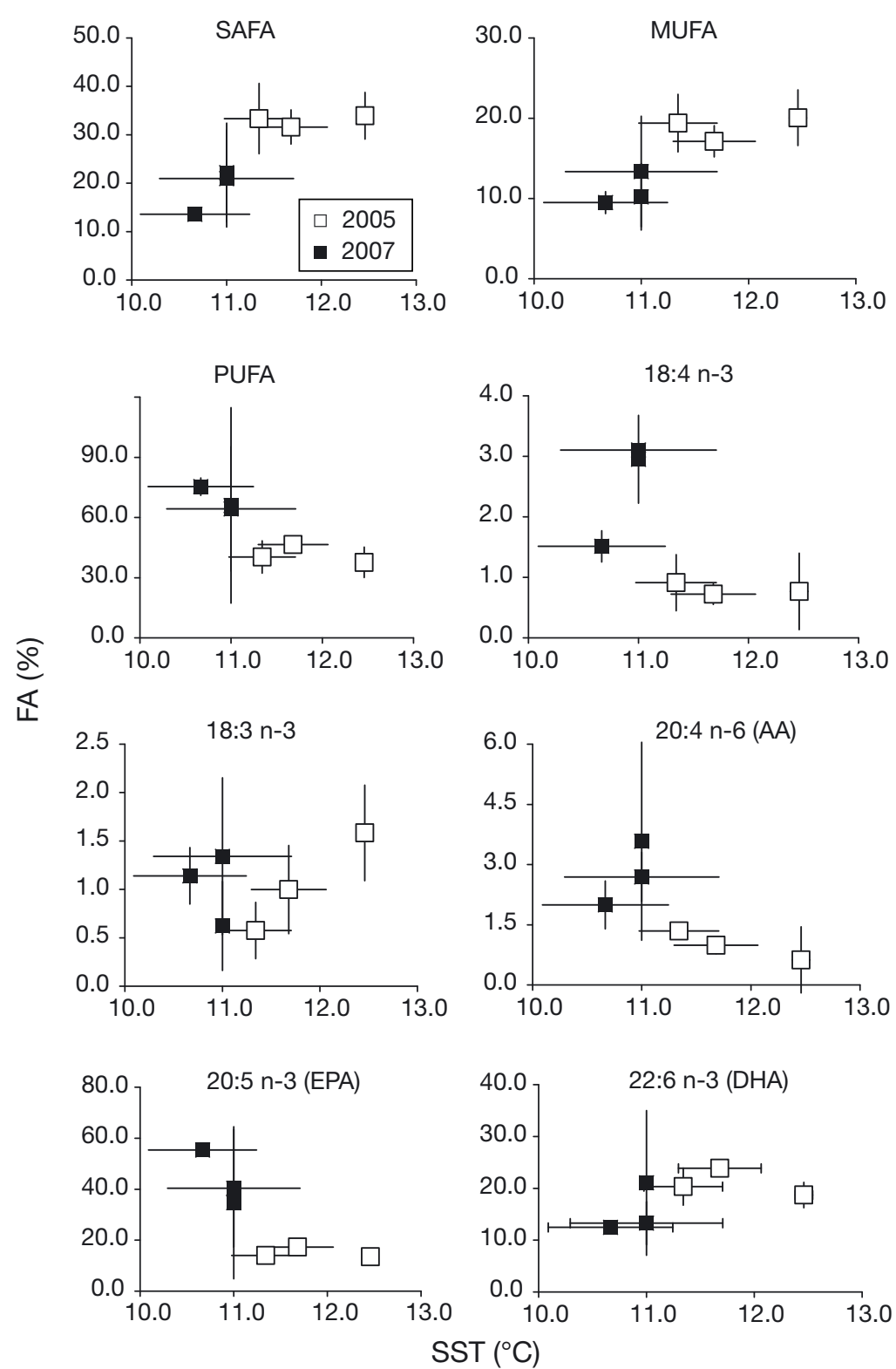

Fig. 4. Engraulis ringens. Sea surface temperature and fatty acids (FAs) in anchoveta eggs collected during 2005 and 2007 cruises to the coastal station. Data: monthly means \pm SD. See Fig. 1 for FA definitions

terms of other characteristics (lipid, protein, and free amino acid contents) have just recently been documented (Castro et al. 2009, Krautz et al. 2010). The use of FA as indicators of egg quality and their potential association with female reproductive traits and environmental conditions have yet to be explored.

The environmental conditions in winters 2005 and 2007 were contrasting. Whereas our monitoring station showed the warmest and freshest water column of the $7 \mathrm{yr}$ time-series in winter 2005, the water column was coldest and the most saline in winter 2007. Our data on surface temperature at the coastal oceanographic sta- tions as well as over the entire region confirm the difference in the thermal regime between these years for the anchoveta spawning zone. The hydrographic information for 2007 and wind data analyses carried out during the same months indicated that south winds occurred inducing upwelling at the coast in winter (Castro et al. 2008), although downwelling usually occurs in the coastal zone during this season (Castro et al. 2000). The different oceanographic conditions found in the 2 studied years also extended to the microand mesozooplankton composition. Mean diatom abundances increased notoriously in 2007. In mid-winter 2005, mostly omnivorous and carnivorous small-sized copepods (Oncaeidae and Oithonidae) predominated, unlike winter 2007, when larger herbivorous-omnivorous calanoid copepods (mostly copepodites and adult Calanidae), typical of upwelling conditions, were predominant. In terms of zooplankton biomass, winter 2007 revealed the highest biomass values during the $7 \mathrm{yr}$ time-series (Castro et al. 2008).

The anchoveta egg volumes differed between the winter spawns of 2005 and 2007. Variations in egg volumes have been recorded for many fish species in response to changes in environmental conditions. In anchoveta, egg sizes have been shown to vary with latitude (larger sizes at higher latitudes) and throughout the spawning season (larger sizes early in the winter spawning season) (Castro et al. 2002, Llanos Rivera \& Castro 2004, 2006). Moreover, the reported variations in the biochemical composition of the eggs (larger eggs contain higher concentrations of total lipids, cholesterol, and proteins) have been interpreted as beneficial for the young larvae in winter, when normal oceanographic conditions for feeding are harsher than during the rest of the year (Castro et al. 2009). Our current results agree with these previous studies in the sense that larger eggs were also observed in the cooler winter (2007). The assumption that there is a relationship between egg size and food availability for young larvae is also supported since smaller-sized copepods (presumably more prone to being captured by the youngest larvae) were most abundant in 2005 when eggs were smaller; their larvae would not need much lipid reserves because small-size food would be more readily available. 


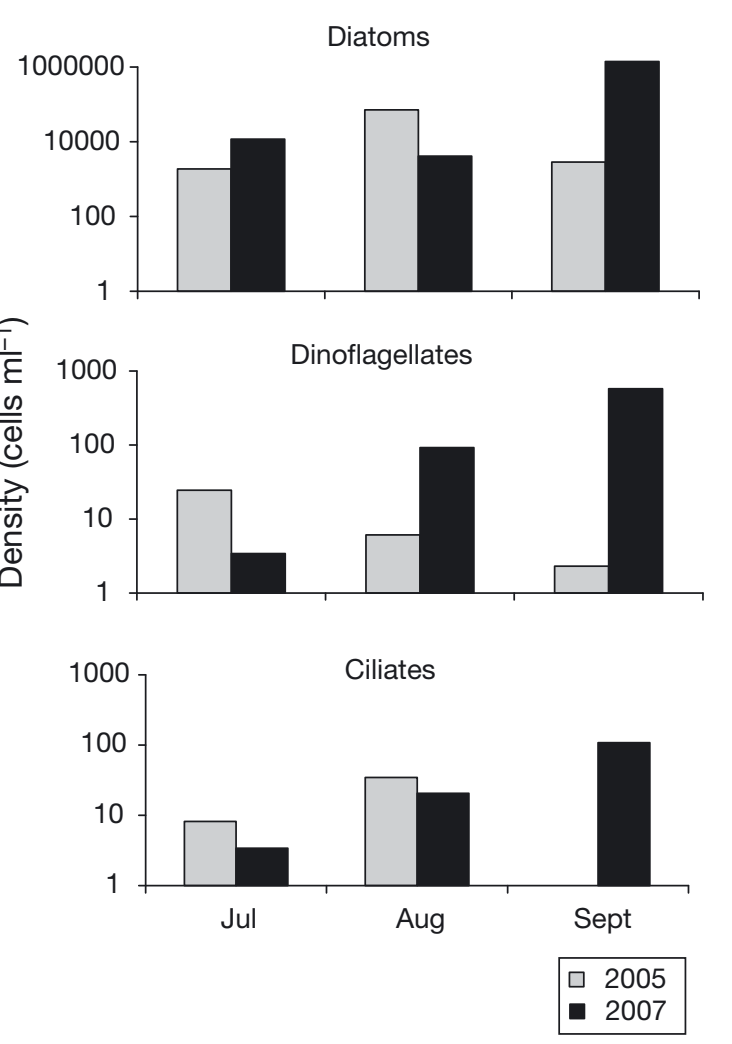

Fig. 5. Density of the most abundant groups of microplankton (diatoms, dinoflagellates, ciliates) and mesozooplankton (Calanidae, Oncaeidae, Oithonidae, appendicularians) in winters 2005 and 2007

The fractions of the FA types (SAFA, MUFA, PUFA) determined in anchoveta eggs in 2005 were within the ranges reported for eggs or female gonads of other marine fish species collected from the wild. However, the values found in 2007 were either in the upper $(68 \%$ PUFA) or the lower (18\% SAFA and $11 \%$ MUFA) range of those reported for most species. These different FA were mostly due to the high values of PUFA as a result of the extremely high EPA values in 2007 ( 34.6 to $55.4 \%$ ). In the literature, the EPA values for eggs, female gonads, or even other fish tissues (muscle, skin, liver) are usually $<20 \%$, including aquaculture fish species fed special diets (Tocher \& Sargent 1984, Navas et al. 1997, Pickova et al. 1997, Sargent et al. 1999, Morehead et al. 2001, Iverson et al. 2002, Njinkoué et al. 2002, Shirai et al. 2002, Li et al. 2005, Salze et al. 2005, Bransden et al. 2007, Garrido et al. 2007, Huynh et al. 2007, Özogul \& Özogul 2007). Causes of our high values are not known but could be due to the combined effect of the direct ingestion of long chain-forming diatoms and large calanoid copepods, and the lower temperatures in 2007.

A relationship was observed between temperature and the FA composition in both years of our study,

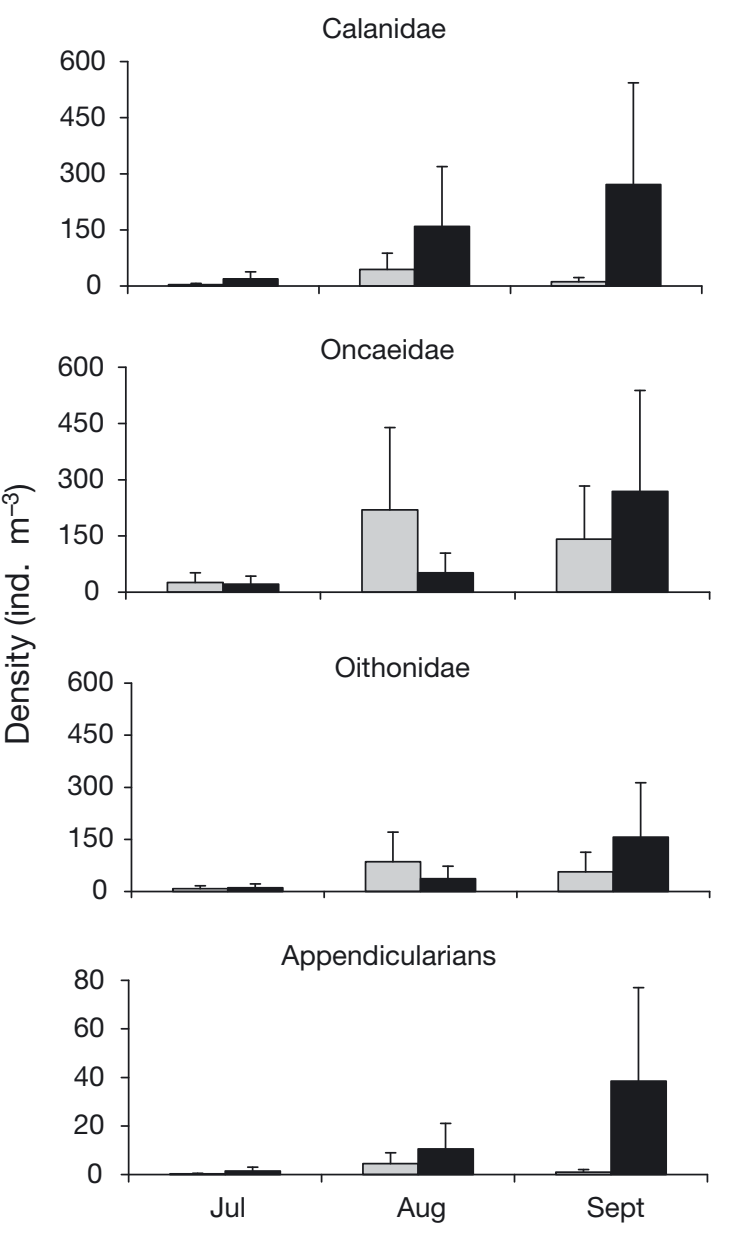

revealing higher PUFA in the eggs collected from the cooler waters (2007) and higher SAFA and MUFA in those from the warmer waters (2005). Interestingly, these results agree with previous reports indicating that PUFA are more abundant in fishes from colder waters, whereas SAFA and MUFA are generally more abundant in temperate or warmer-water fishes (Halver 1980, Magalhães et al. 2010). From a biological point of view, growth of most poikilotherms at low temperatures usually leads to increased levels of PUFA rather than monoenes in their membrane lipids (Hazel 1995). Litz et al. (2010) recently reported a coincidence within upwelling areas between differences of $\sim 1$ to $3^{\circ} \mathrm{C}$ in seawater temperature (early vs. late summer) and changes in FA composition in forage fishes (e.g. northern anchovy, Pacific sardine, Pacific herring of the California Current). Also, they reported that $\sim 1$ to $2^{\circ} \mathrm{C}$ difference between the early summers and between the late summers of 2005 and 2006 coincided with differences in FA composition in these small pelagic fishes. However, since changes in temperature occurred in conjunction with variations in productivity due to the incorporation of nutrients into the photic zone through coastal upwelling, the effect of temperature cannot be 

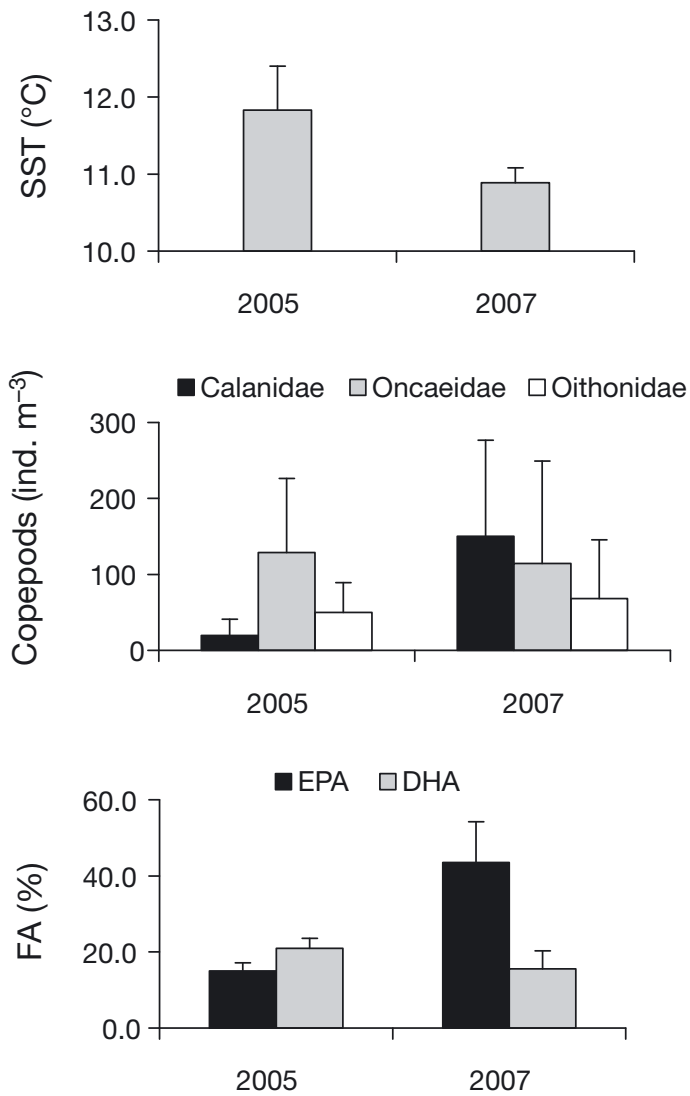
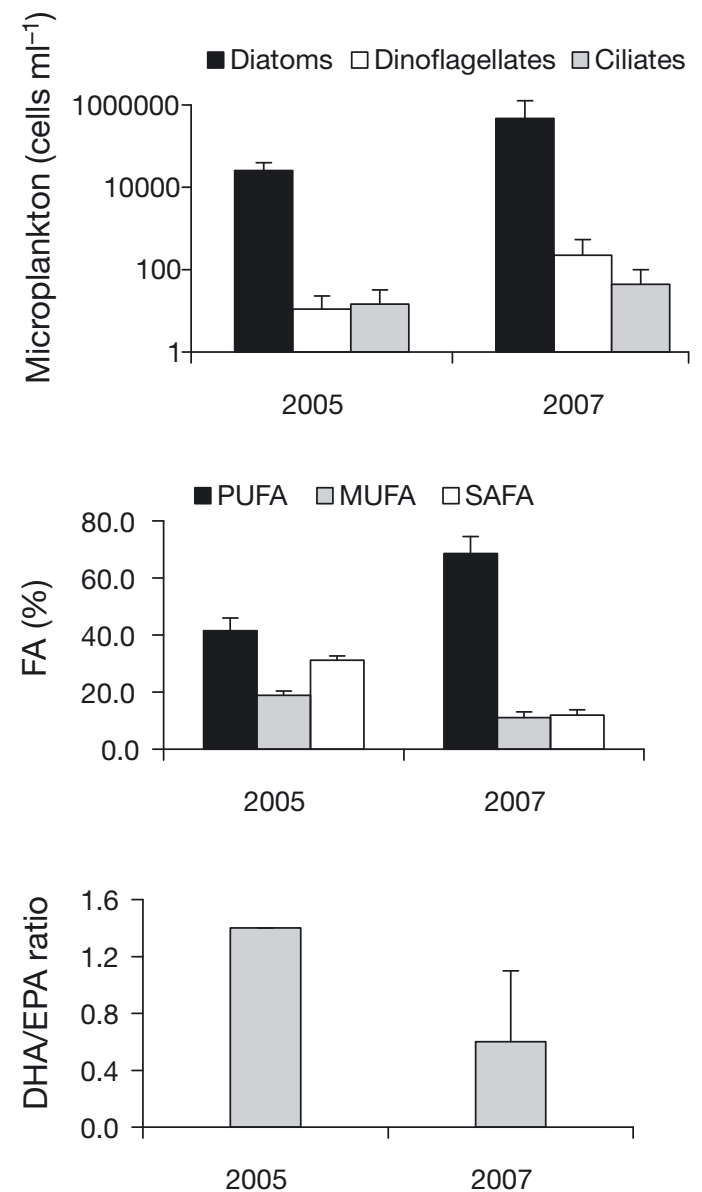

Fig. 6. Engraulis ringens. Sea surface temperature (SST), mean density of the most abundant planktonic groups, fatty acid (FA) classes (see Fig. 1 for definitions), and docosahexaenoic (DHA), eicosapentaenoic acid (EPA), and DHA/EPA ratio in anchoveta eggs during the winters 2005 and 2007

isolated from other environmental factors. In the case of upwelling areas such as the California Current, changes in environmental conditions include notorious shifts in productivity and plankton composition (diatoms, dinoflagellates); thus, changes in the FA composition of forage fishes were explained mainly based on variations in their food quality in the field (Litz et al. 2010).

In the present study, the differences among FA classes in anchoveta eggs may also have resulted from changes in the edible food availability, as suggested by the analysis of prey items for females during the contrasting sampling seasons (2005 vs. 2007). Our results show that small-sized copepods (Oncaeidae, Oithonidae) dominated in winter 2005. Cyclopoid and poecillostomid copepods such as oithonids and Oncaea spp. have been reported in anchoveta guts in central Chile (Rebolledo \& Cubillos 2003) as well as in anchovies from other regions (van der Lingen et al. 2009). The FA composition of zooplankton is determined by the type of food sources they ingest. Oncaeidae and
Oithonidae copepods have been reported to be mainly omnivores, detritivores, or carnivores (Go et al. 1998, Castellani et al. 2005). Besides feeding on microalgae, these copepods can prey heavily on ciliates, rotifers, and copepod nauplii, among other small-sized prey (Wickham 1995). Ciliates, although usually considered to be herbivores, may be major consumers of heterotrophic flagellates that, in turn, consume bacteria. Therefore, these small copepods may constitute a link between the classical and microbial food webs (Gifford 1991, Nakamura \& Turner 1997). Recent studies have demonstrated that Oithonidae and Oncaeidae copepods have distinctive FA compositions that may distinguish them from other zooplankters (Kattner et al. 2003). In the same area of our study, Vargas et al. (2006) found changes in the FA composition of copepods and in their egg production throughout the year and associated them with the results for the different feeding conditions occurring at different times of the year. Late in autumn and winter, higher SAFA and MUFA were observed in copepods as a result of a 
change in feeding: large phytoplankton in summer versus small ciliates and dinoflagellates in winter. Springtime primary production and diatom-based feeding were accompanied by increased copepod PUFA and egg production. Our results resemble those of Vargas et al. (2006) in the sense that, in more productive seasons, PUFA constituted the largest fraction of FA in anchoveta eggs, possibly resulting from the consumption of larger-sized phytoplankton (usually rich in PUFA; Dalsgaard et al. 2003) by larger herbivore calanoid copepods, as observed in 2007, or from the direct consumption of larger-sized phytoplankton by female anchovetas. Alternatively, in the less productive, warmer winter (2005), when SAFA and MUFA were dominant in the eggs, female anchovies fed on the more abundant, smaller-sized cyclopoid and poecillostomid copepods (these, in turn, might have fed on small ciliates and dinoflagellates). An alternative source of support for this food-web hypothesis may be drawn from the typical FA composition of dinoflagellates and diatoms, the typical phytoplankton groups in low and high production seasons. Budge \& Parrish (1998) stated that a DHA/EPA ratio $\geq 1$ may indicate the dominance of dinoflagellates, whereas values $<1$ could suggest a greater contribution of diatoms. Applying this criterion, our results for the DHA/EPA ratios in anchoveta eggs between spawning seasons support the hypothesis of an increased proportion of DHA from dinoflagellates incorporated into females through the small Oncaea copepods abundant in the less productive, warm winter 2005 and a higher proportion of EPA from diatoms in the more productive, cold winter 2007 , when larger herbivore copepods were more abundant in the area.

The overall biological environmental conditions (larger copepods, highest zooplankton biomass in many years), reproductive characteristics (larger gonads, increased batch and relative fecundity), egg size (larger egg volumes, which have been reported to correlate with total lipids and increased hatch success), and biochemical indicators of egg quality (higher PUFA) suggest that the fate of the spawn in 2007 should have been good. However, this particular set of characteristics cannot arise in this environment and population without the presence of unusual upwellingfavorable winds in the area for several weeks in winter (Castro et al. 2008). Interestingly, the occurrence of this process may also have involved major trade-offs for small pelagic fish populations because these winds induce the transport of eggs and larvae away from the coastal environment, which has rich, favorable conditions for larval development. In low latitude areas, winter upwelling is the norm, and young offspring are not transported far from the coast because the net seaward flux is not high (given the deep depth of the mixed layer) (Bakun 1996). However, at mid-latitudes such as off Concepción (36 to $37^{\circ} \mathrm{S}$ ), Chile, the seaward transport of eggs and larvae may be intense since the depth of the mixed layer is very shallow. Thus, potentially beneficial conditions in the feeding environment and population biology of mid-latitude areas such as Talcahuano may not necessarily result in high recruitment and immediate increments in the biomass of fish stocks because the benign conditions (e.g. those of the 2007 spawning season) have to be balanced with other environmental trade-offs that may be more important in this area than at other latitudes (Cury \& Roy 1989).

Acknowledgements. Financial support for this study was obtained from the grant FONDECYT 1070502 to L.R.C. and G.C. Reproductive data were obtained from the grants FIP 2007-06 and FIP 2005-02. Oceanographic data from Stn 18 were provided by the COPAS Center Time Series (FONDAP Program, Project 150100007) and grant FIP 2007-10 to L.R.C. and colleagues. Fatty acid analyses were carried out at the Pharmacology Laboratory of the Universidad Austral de Chile. The monthly cruises, egg collections, and laboratory work were carried out by personnel at LOPEL (M.I. Muñoz, P. Barrientos, P. Vásquez, A. Yañez, S. Vásquez, and other collaborators). D. Donoso helped with hydrography figures. Satellite images were processed by C. Silva. Thanks to the RV 'Kay Kay' crew, R. Torres, and the personnel at the Marine Biology Station in Dichato, which was recently destroyed by a tsunami.

\section{LITERATURE CITED}

Ayon P (2000) El método de producción diaria de huevos en la estimación de la biomasa desovante del stock norte-centro de la anchoveta peruana. Bol Inst Mar Perú 19:7-14

Bakun A (1996) Reproductive activity has a time and place. In: Bakun A (ed) Patterns in the ocean: ocean processes and marine population dynamics. Cali Sea Grant Prog, San Diego, CA, p 135-157

Blaxter J, Hempel G (1963) The influence of egg size on herring larvae (Clupea harengus). J Cons Perm Int Explor Mer 28:211-240

Bransden MP, Battaglene SC, Goldsmid RM, Dunstan GA, Nichols PD (2007) Broodstock condition, egg morphology and lipid content and composition during the spawning season of captive striped trumpeter, Latris lineata. Aquaculture 268:2-12

Budge SM, Parrish CC (1998) Lipid biogeochemistry of plankton, settling matter and sediments in Trinity Bay, Newfoundland. II. Fatty acids. Org Geochem 29:1547-1559

Cantellops D, Reid AP, Eitenmiller RR, Long AR (1999) Determination of lipids in infant formula powder by direct extraction methylation of lipids and fatty acids methyl esters (FAME) analyses by gas chromatography. J AOAC Int 82:1128-1139

Carrillo M, Zanuy S, Oyen F, Cerdá J, Navas JM, Ramos J (2000) Some criteria of the quality of the progeny as indicators of physiological broodstock fitness. In: Chioccioli E (ed) Recent advances in Mediterranean aquaculture finfish species diversification, Vol 47. Cahiers Options Méditerranéennes: CIHEAM-IAMZ, Zaragoza Castellani C, Irigoien X, Harris RP, Lampitt RS (2005) Feeding 
and egg production of Oithona similis in the North Atlantic. Mar Ecol Prog Ser 288:173-182

Castro LR (2001) Environmental conditions and larval survival during the winter spawning season of the southernmost anchoveta stock off Chile. GLOBEC Newsletter 7: $15-17$

> Castro LR, Salinas GR, Hernández EH (2000) Environmental influences on winter spawning of the anchoveta Engraulis ringens off Central Chile. Mar Ecol Prog Ser 197: $247-258$

Castro L, Llanos A, Blanco JL, Tarifeño E, Escribano R, Landaeta M (2002) Influence of latitudinal variations in spawning habitat characteristics on the early life history traits of the anchoveta, Engraulis ringens, off northern and central Chile. GLOBEC Report 16:42-45

Castro L, Daneri G, Escribano R, Farías L, González H, Morales C, Pizarro O (2008) Monitoreo de las condiciones oceanográficas en la VIII y IX Región, año 2007. Informe Final, Proyecto FIP 2007-10. Departamento de Pesquerias \& Instituto de Investigacion Pesquera, Talcahuano

$>$ Castro LR, Claramunt G, Krautz MC, Llanos-Rivera A, Moreno P (2009) Egg trait variation in anchoveta Engraulis ringens: a maternal response to changing environmental conditions in contrasting spawning habitats. Mar Ecol Prog Ser 381:237-248

Chambers RC (1997). Environmental influences on egg and propagule sizes in marine fishes. In: Chambers RC, Trippel EA (eds) Early life history and recruitment of fish populations. Chapman \& Hall, London, p 63-102

$>$ Ciechomski J (1973) The size of the egg of the Argentine anchovy Engraulis anchoita in relation to the season of the year of spawning. J Fish Biol 5:393-398

Cury P, Roy C (1989) Optimal environmental window and pelagic fish recruitment success in upwelling areas. Can J Fish Aquat Sci 46:670-680

Cury P, Bakun A, Crawford RJM, Jarre A, Quiñones RA, Shannon LJ, Verheye HM (2000) Small pelagics in upwelling systems: patterns of interaction and structural changes in 'wasp-waist' ecosystems. J Mar Sci 57:603-618

Dalsgaard J, St. John M, Kattner G, Muller-Navarra D, Hagen W (2003) Fatty acid trophic markers in the pelagic marine environment. Adv Mar Biol 46:226-340

> Dwyer KS, Parrish CC, Brown JA (2003) Lipid composition of yellowtail flounder (Limanda ferruginea) in relation to dietary lipid intake. Mar Biol 143:659-667

Evans RP, Parrish CC, Brown JA, Davis PJ (1996) Biochemical composition of eggs from repeat and first-time spawning captive Atlantic halibut (Hippoglossus hippoglossus). Aquaculture 139:139-149

Fisher W (1958) Huevos, crias y larvas de anchoveta Engraulis ringens Jenyns. Rev Biol Mar 8:111-124

Garrido S, Rosa R, Ben-Hamadou R, Cunha ME, Chicharo MA, van der Lingen CD (2007) Effect of maternal fat reserves on fatty acid composition of sardine (Sardina pilchardus) oocytes. Comp Biochem Physiol B 148: 398-409

Gifford DJ (1991) The protozoan-metazoan trophic link in pelagic ecosystems. J Protozool 38:81-86

Go YB, Oh BC, Terazaki M (1998) Feeding behavior of the poecilostomatoid copepods Oncaea spp. on chaetognaths. J Mar Syst 15:475-482

Halver JE (1980). Lipids and fatty acids. In: Chow (KW) Fish feed technology. ADCP/REP/80/11. FAO, Rome

> Hazel JR (1995) Thermal adaptations in biological membranes: Is homeoviscuous adaptation the explanation? Annu Rev Physiol 57:19-42

Hunter JR, Goldberg SR (1980) Spawning incidence and batch fecundity in northern anchovy, Engraulis mordax. Fish Bull 77:641-652

Huynh MD, Kitts DD, Hu C, Trites AW (2007) Comparison of fatty acid profiles of spawning and non-spawning Pacific herring, Clupea harengus pallasi. Comp Biochem Physiol B 146:504-511

Iverson SJ, Frost KJ, Lang SL (2002) Fat content and fatty acid composition of forage fish and invertebrates in Prince William Sound, Alaska: factors contributing to among and within species variability. Mar Ecol Prog Ser 241:161-181

Kattner G, Albers C, Graeve M, Schmack-Schield SB (2003) Fatty acid and alcohol composition of the small polar copepods Oithona and Oncaea: indication on feeding modes. Polar Biol 26:666-671

> Krautz MC, Castro LR, González M (2007) Interaction of two key pelagic species of the Humboldt Current: euphausiid predation on anchoveta eggs estimated by immunoassays. Mar Ecol Prog Ser 335:175-185

Krautz MC, Vásquez S, Castro LR, González M, Llanos-Rivera A, Pantoja S (2010) Changes in metabolic substrates during the early developmental stages of anchoveta Engraulis ringens (Jenys 1842) in the Humboldt Current. Mar Biol 157:1137-1149

Lahnsteiner F, Patarnello P (2005) The shape of the lipid vesicle is a potential marker for egg quality determination in the gilthead seabream, Sparus aurata, and in the sharpnose seabream, Diplodus puntazzo. Aquaculture 246: 423-435

Lasker R, Theilacker GH (1962) The fatty acid composition of the lipids of some Pacific sardine tissues in relation to ovarian maturation and diet. J Lipid Res 3:60-64

$>$ Leal E, Castro LR, Claramunt G (2009) Variability in oocyte size and batch fecundity of two anchovy stocks (Engraulis ringens, Jenyns 1842) off the Chilean coast. Sci Mar 73: $59-66$

> Li Y, Chen W, Sun Z, Chen J, Wu K (2005) Effects of n-3 HUFA content in broodstoock diet on spawning performance and fatty acid composition of eggs and larvae in Plectorhynchus cinctus. Aquaculture 245:263-272

Litz MNZ, Brodeur RD, Emmett RL, Heppell SS, Rasmussen RS, O'Higgins L, Morris MS (2010) Effects of variable oceanographic conditions on forage fish lipid content and fatty acid composition in the northern California Current. Mar Ecol Prog Ser 405:71-85

Llanos-Rivera A, Castro LR (2004) Latitudinal and seasonal egg size variations of the anchoveta Engraulis ringens off the Chilean coast. Fish Bull 102:207-212

> Llanos-Rivera A, Castro LR (2006) Inter-population differences in temperature effects on Engraulis ringens yolk sac larvae. Mar Ecol Prog Ser 312:245-253

Magalhães BS, Fiamoncini J, Deschamps FC, Curi R, Silva LP (2010) Comparison of fatty acid composition in nine organs of the sympatric Antarctic teleost fish species Notothenia rossi. Comp Biochem Physiol B 155:132-137

> Mayzaud P, Virtue P, Albessard E (1999) Seasonal variations in the lipid and fatty acid composition of the euphausiid Meganyctiphanes norvegica from the Lugurian Sea. Mar Ecol Prog Ser 186:199-210

> Morehead DT, Hurt PR, Dunstan GA, Brown M, Punkhurst NW (2001) Differences in egg quality between wild striped trumpeter (Latris lineata) and captive striped trumpeter that were fed different diets. Aquaculture 192:39-53

> Nakamura Y, Turner JT (1997) Predation and respiration by the small cyclopid copepod Oithona similis: How important is feeding on ciliates and heterotrophic flagellates? J Plankton Res 19:1275-1288

Navas JM, Bruce M, Thrush M, Farndale BM and others 
(1997) The impact of seasonal alteration in the lipid composition of broodstock diets on egg quality in the European sea bass. J Fish Biol 51:760-773

Njinkoué JM, Barnathan G, Miralles J, Gaydou EM, Samb A (2002) Lipids and fatty acids in muscle, liver and skin of three edible fish from the Senegalese coast: Sardinella maderensis, Sardinella aurita and Cephalopholis taeniops. Comp Biochem Physiol 131B:395-402

Özogul Y, Özogul F (2007) Fatty acid profiles of commercially important fish species from the Mediterranean, Aegean and Black Seas. Food Chem 100:1634-1638

Parker K (1980) A direct method for estimating northern anchovy, Engraulis mordax, spawning biomass. Fish Bull 78:541-544

Pickova J, Dutta PC, Larson PO, Kiessling A (1997) Early embryonic cleavage pattern, hatching success, and egglipid fatty acid composition: comparison between two cod stocks. Can J Fish Aquat Sci 54:2410-2416

Rainuzzo JR, Reitan KI, Olsen Y (1997) The significance of lipids at early stages of marine fish: a review. Aquaculture 155:103-105

Rebolledo H, Cubillos L (2003). Items alimentarios de la anchoveta y sardina común en la zona Centro-sur durante el verano del 2003. In: Castillo J (ed) Evaluación hidroacústica del reclutamiento de anchoveta y sardina común entre la V y X Regiones, año 2002. Informe Final FIP 2002-13. Fondo Investigación Pesquera, Valparaíso (available at www.fip.cl/FIP/ archivos/pdf/informes/inffinal $\%$ 202002-13.pdf)

Rideout RM, Trippel EA, Litvak MK (2005) Effects of egg size, food supply and spawning time on early life history success of haddock Melanogrammus aeglefinus. Mar Ecol Prog Ser 285:169-180

Riveiro I, Guisande C, Lloves M, Maneiro I, Cabanas JM (2000) Importance of parental effects on larval survival in Sardina pilchardus. Mar Ecol Prog Ser 205:249-258

Riveiro I, Guisande C, Maneiro I, Vergara AR (2004) Parental effects in the European sardine Sardine pilchardus. Mar Ecol Prog Ser 274:225-234

Editorial responsibility: Hans Heinrich Janssen, Oldendorf/Luhe, Germany
Saito H, Murata M (1998) Origin of the monoene fats on the lipid of midwater fishes: relationship between the lipids of myctophids and those of their prey. Mar Ecol Prog Ser 168:21-33

Salze G, Tocher DR, Roy WJ, Robertson DA (2005) Egg quality determinants in cod (Gadus mohua L.): egg performance and lipids in eggs from farmed and wild broodstocks. Aquacult Res 36:1488-1499

Sargent J, McEvoy L, Estevez A, Bell G, Bell M, Henderson J, Tocher D (1999) Lipid nutrition of marine fish during early development: current status and future directions. Aquaculture 179:217-229

Shields RJ, Brown NP, Bromage NR (1997) Blastomere morphology as a predictive measure of fish egg viability. Aquaculture 155:1-12

Shirai N, Terayama M, Takeda H (2002) Effect of season on the fatty acid composition and free amino acid content of the sardine Sardinops melanostictus. Comp Biochem Physiol B 131:387-393

St John MA, Lund T (1996) Lipid biomarkers: linking the utilization of frontal plankton biomass to enhanced condition of juvenile North Sea cod. Mar Ecol Prog Ser 131:75-85

> Tocher DR, Sargent JR (1984) Analysis of lipids and fatty acids in ripe roes of some Northwest European marine fish. Lipids 19:492-499

Utermöhl H (1958) Zur Vervollkommnung der quantitativen Phytoplankton-Methodik. Verh Internat Verein Limnol 9:1-39

van der Lingen $C D$, Bertrand A, Bode A, Brodeur R and others (2009). Trophic dynamics. In Checkley D, Alheit J, Oozeki Y, Roy C (eds) Climate Change and Small Pelagic Fish, Cambridge University Press, New York, NY, p 112-157

Vargas CA, Escribano R, Poulet S (2006) Phytoplankton food quality determinates time windows for successful zooplankton reproductive pulses. Ecology 87:2992-2999

> Wickham S (1995) Trophic relations between cyclopoid copepods and ciliated protists: complex interactions link the microbial and classic food webs. Limnol Oceanogr 40: $1173-1181$

Submitted: February 8, 2010; Accepted: September 8, 2010 Proofs received from author(s): December 9, 2010 